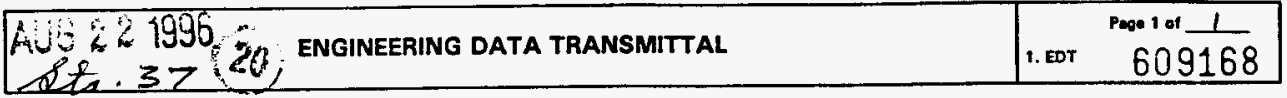

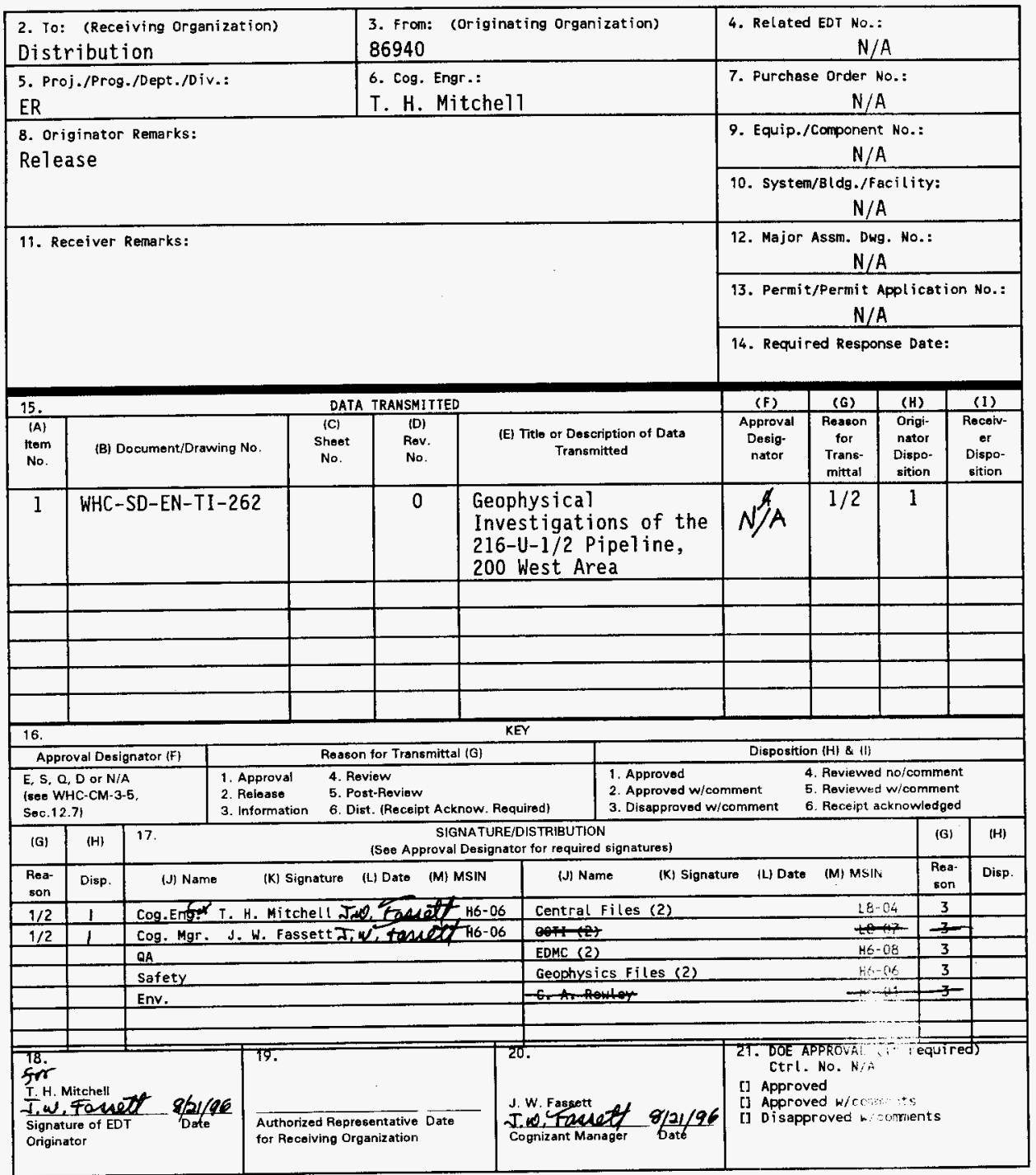

BD-7400-172-2(04/94) GEF097 


\title{
Geophysical Investigation of the 216-U-1/2 Pipeline, 200 West Area
}

\author{
K. A. Bergstrom \\ T. H. Mitchell \\ West inghouse Hanford Company, Richland, WA 99352 \\ U.S. Department of Energy Contract DE-AC06-87RL10930 \\ EDT/ECN: 609163 \\ Org Code: $8 \mathrm{H} 100$ \\ B\&R Code: EW3120100 \\ UC: 630 \\ Charge Code: R4V11 \\ Total Pages: 13
}

Key Words: Ground-penetrating radar, Geophysics, 216-U-1/2 Cribs

Abstract: Ground-penetrating radar was used at three locations in an attempt to locate and determine the depth of the 216-U-1/2 pipeline. Many anomalies were found, all very useful to the project, but only some of which were identified with the pipeline.

TRADEMARK DISCLAIMER. Reference herein to eny specific commercial product, process, or service by trade name, trademark, manufacturer, or otherwise, does not necessarily constitute or imply its endorsement, recommendation, or favoring by the United States Government or any agency thereof or its contractors or subcontractors.

Printed in the United States of America. To obtain copies of this document, contact: WHC/BCS Document Control Services, P.O. Box 1970, Mailstop H6-08, Richland WA 99352, Phone (509) 372-2420; Fax (509) 376.4989 .
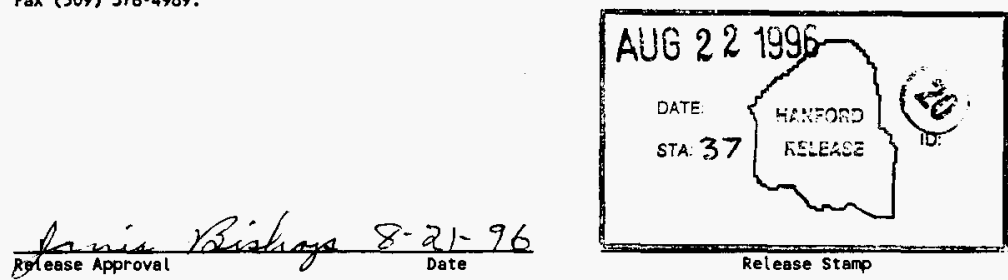

Approved for Public Release 
WHC-SD-EN-TI-262, Rev.0

\section{CONTENTS}

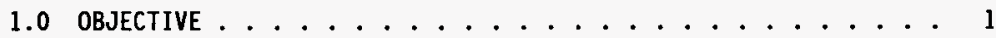

2.0 GROUND-PENETRATING RADAR METHODOLOGY $\ldots \ldots \ldots \ldots$

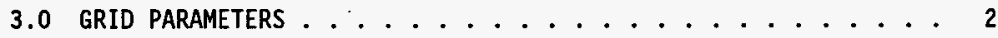

4.0 QUALITY CONTROL .................. 2

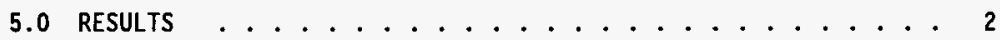

\section{FIGURES:}

1. Location Map ................... 5

2. Interpretation map of geophysical surveys over the $216-U-1 / 2$ pipeline, Site \#1 ............. 6

3. Interpretation map of geophysical surveys over the $216-U-1 / 2$ pipeline, Site \#2 ............. 7

4. Interpretation map of geophysical surveys over the $216-4-1 / 2$

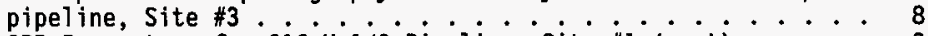

5. GPR Parameters for 216-U-1/2 Pipel ine, Site \#1 (west) . . . . 9

6. GPR Parameters for 216-U-1/2 Pipeline, Site \#2 (centra1) ... 10

7. GPR Parameters for 216-U-1/2 Pipeline, Site \#3 (east) ..... 11 
WHC-SD-EN-TI-262, Rev.0

\subsection{OBJECTIVE}

A geophysical investigation was conducted to the south of U-PIant (Figure 1) in an attempt to map portions of the $216-\mathrm{U}-1 / 2$ pipeline. The 216-U-1/2 pipeline was used to transport radioactive waste from U-Plant to the $216-U-1 / 2$ cribs located approximately $900 \mathrm{ft}$ to the west of $U-$ Plant. Ground-penetrating radar (GPR) was the method selected for the investigation. GPR surveys were conducted at three sites along the pipeline. The objectives of the surveys were to locate/confirm the pipe location and to delineate any subsurface obstructions that might affect the test pits over the pipe.

\subsection{GROUND-PENETRATING RADAR METHODOLOGY}

The GPR system used for this work utilized 300-megahertz (MHz) transducer. The transducer transmits electromagnetic energy into the ground. Buried objects such as pipes, barrels, foundations, and buried wires can cause all, or a portion, of the transmitted energy to be reflected back towards a receiving antenna. Geologic features such as crossbedding, caliche horizons, paleosols, and clays can also cause reflections of the transmitted energy. The reflected energy provides the means for mapping the subsurface features of interest, whether manmade or geologic.

The maximum depth of investigation varies from site to site, and is a function of the transmit power, receiver sensitivity, frequency of the antenna, and attenuation of the transmitted energy. The attenuation of the energy is primarily a function of the local soil conditions. The depth of investigation is also affected by highly conductive material, such as metal drums and pipes which essentialiy reflect all the energy. The method cannot "see" directly below areas of highly reflective material since "all" of the energy is reflected. Maximum depth of penetration for these surveys ranged from about 10 to $12 \mathrm{ft}$.

Display and interpretation of GPR data are similar to that of seismic reflection data (i.e., data displayed as horizontal distance vs. time, depicting pseudo cross-sections of the earth). The approach to an interpretation is quite variable and influenced by the objectives of the survey and the experience of the interpreter. There are al so numerous data processing techniques available that may or may not aid in the interpretation process. In some areas, interpretations can be straight forward, but often a highly variable subsurface yields complex data that is difficult to interpret. A common end product is a plan-view map showing the locations and depths of the features that were detected within the survey area.

\footnotetext{
1

Team Geophysics/Geoscience Group WHC
} 
WHC-SD-EN-TI-262, Rev.0

GPR data in these surveys were collected with a Geophysical Survey Systems Inc. (GSSI) Subsurface Interface Radar (SIR) ${ }^{-1}$ System 8, model 4800 , and digitally stored with a GSSI DT6000A tape drive. A recording window of 100 nanoseconds, two-way travel time, was used at all sites.

\subsection{GRID PARAMETERS}

A rectangular grid was used at each of the three sites. The western most grid, Site \#1 measured $40 \mathrm{ft} \times 90 \mathrm{ft}$ (Figure 2). The central grid, Site \#2 measured $40 \mathrm{ft} \times 70 \mathrm{ft}$ (Figure 3 ), and the eastern grid, Site \#3, measured $50 \mathrm{ft} \times 60 \mathrm{ft}$ (Figure 4). Painted stakes or paint mark the corners of each grid. The long axis of each survey strikes approximately north to northeast. All distances were measured and posted in feet. The southwestern corner of each grid was independently designated as E100/N100 and served as the "origin" for each survey site. The letters " $E$ " or " $N$ " refer to a direction that trends generally east or north, respectively. The number refers to a distance in feet. For example, grid point E135/N120 lies $35 \mathrm{ft}$ "east" and $20 \mathrm{ft}$ "north" of the grid point E100/N100.

At each of the sites the data were collected along two sets of profiles perpendicular to each other. An additional set of diagonal lines were collected in the eastern site. Spacing between profiles was $5 \mathrm{ft}$ at all three sites.

\subsection{QUALITY CONTROL}

These data were collected using procedures in WHC-CM-7-7, EII 11.2, Rev. 3, Environmental Investigations and site Characterization Manual, Westinghouse Hanford Company. The data and records are stored in the Geophysics files. Figures 5, 6, and 7 summarize survey parameters.

\subsection{RESULTS}

Site \#1 is the site closest to the $216-U-1 / 2$ cribs. An east-west striking linear anomaly was detected along $\mathrm{N12l}$. The anomaly is buried about seven feet below the surface. The location and depth is consistent with the predicted location and depth of the pipeline.

n A trademark of Geophysical Survey Systems Inc. (GSSI).

2 
The northern excavation boundary for the pipeline is interpreted at about N135. The southern excavation boundary for the interpreted pipe was not delineated primarily because there are numerous anomalies in the area that are probably masking the excavation boundaries.

Located immediately above the N12l linear is another linear anomaly, about two feet below the surface. It appears to terminate at about E132. It could be a significant linear (i.e., utility/pipeline), or it could be debris thrown into the back-filled excavation for the pipeline.

Several other linears were also detected at Site \#1. Along about E140 and E145, there are two sets of stakes that appear to be the kind used to mark the location of buried utilities. The stakes correlate with two north-south linears that were detected about three feet below the surface suggesting that the linears are two parallel utilities. The E140 and E145 linears pass about ten feet. west of an exposed water valve mapped at about E155/N115 then appear to cross over the N121 linear.

A northwest-southeast striking linear, was detected in the southwest corner of the survey area that also crosses over the N121 linear. It is less than two feet below the surface.

Two other east-west striking linears were detected at about N102 and N182. The N102, a linear is about $3 \mathrm{ft}$ below the surface and the N182 linear is 6-7 ft below the surface. The N182 linears is very similar in character to the N121 linear.

Initially, Site \#2, the central survey site, (Figure 3 ), was located based on a gross projection of the pipeline from the cribs to the U-Plant facility. This site is on a parking lot/road centered near a gate and several small buildings. Several linears are observed in the data. One trends roughly north-south at two feet below the surface. All the others strike east-west at three to four feet below the surface. None of the linears could be clearly correlated with the pipeline of interest. Facility drawings examined after this survey revealed several east-west 1 inears in this vicinity and indicated that the pipe of interest might be slightly south of this survey area.

Based on the facility drawings and indications from an induction pipe detector, Site \#3, was estabiished near the 2715 building (Figure 4).

At Site \#3, two zones were identified that contain numerous subsurface features/debris (Figure 4). The high concentration of anomalies in these zones makes correlation of anomalies (i.e., 
identification of linear pipes/utilities) through these zones difficult or impossible. There were four east-west linears identified in the southern most corner of the grid. They range from 1.5 to $4 \mathrm{ft}$ below the surface (Figure 4). The two 4-ft-deep linears were traced to a nearby fire hydrant. The two shallow linears appear to continue on to the west.

Based on available drawings showing the locations of buried utilities and the results from the GPR work conducted at Site \#1, the pipe of interest was expected to be five to ten feet below the surface. However there were no linears detected at these depths.

Two additional east-west linears were detected that were difficult to trace because they went into and possibly through the debris zones previously mentions. The curvilinear anomaly is a very subtle feature that was detected at a depth of $1.5 \mathrm{ft}$. It correlates with an induction line locator anomaly. Spatially, these two anomalies both correlate with the anticipated location of the 216-U-1/2 pipe based on facility drawings. However, they both are at a shallower depth than that anticipated for the pipe. The possibility exists that the shallow anomaly/features could be masking a deeper anomaly from a pipe. Site \#1 had a similar scenario where a shallow anomaly was observed over the deeper anomaly that was interpreted to be the pipe of interest. 


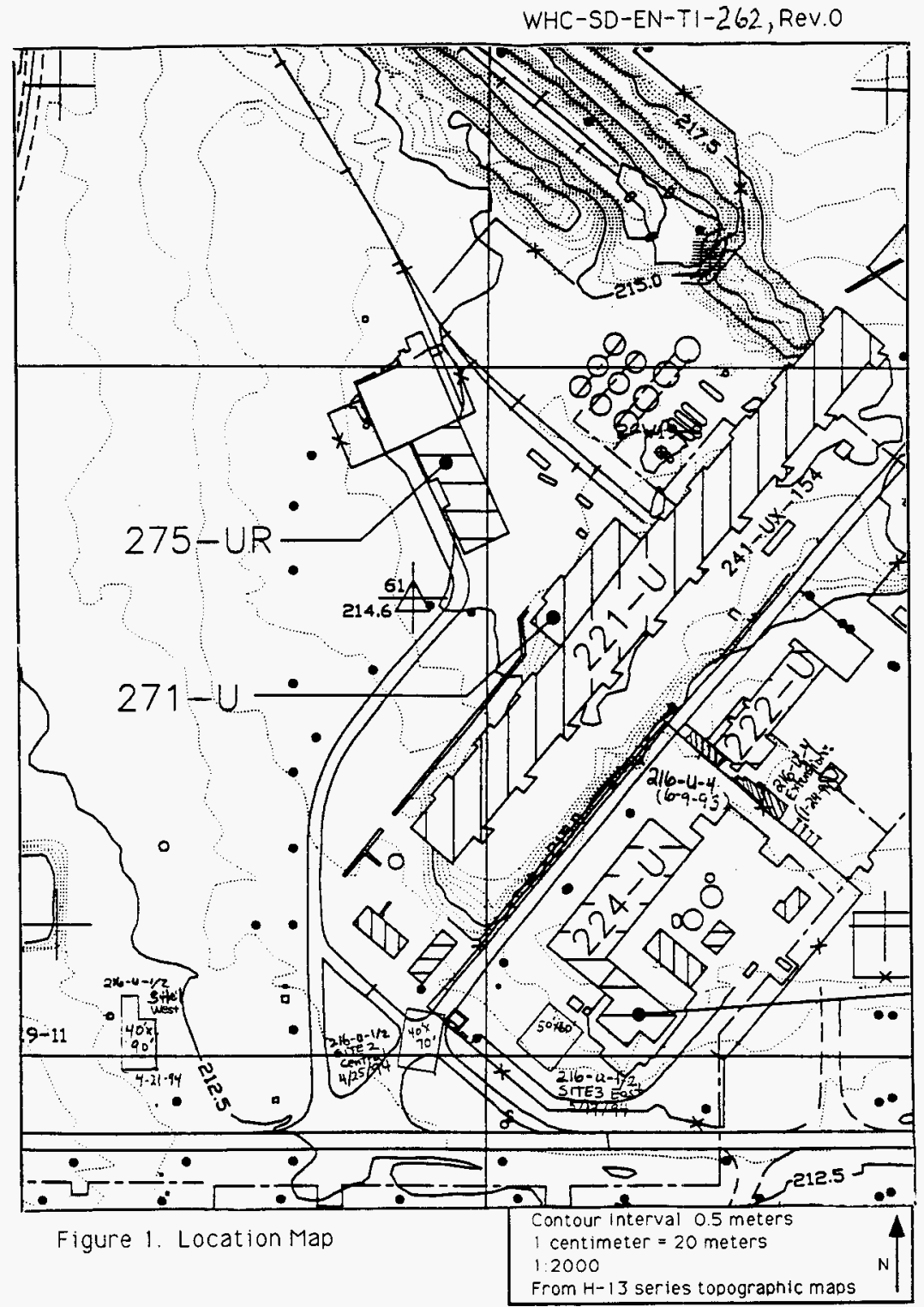




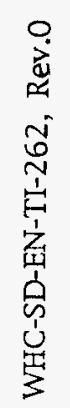

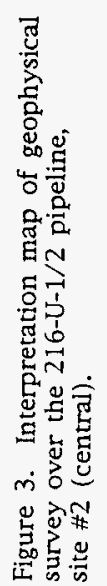

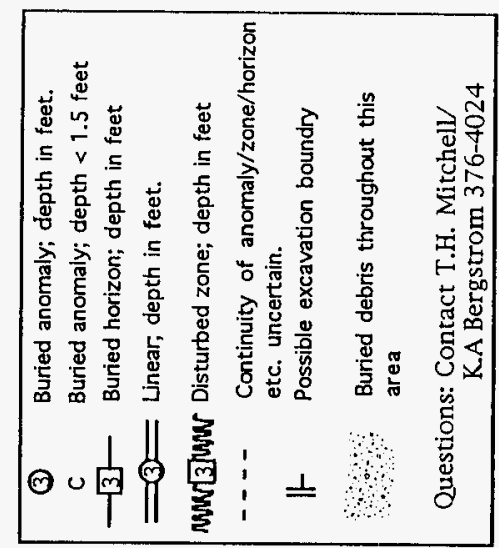

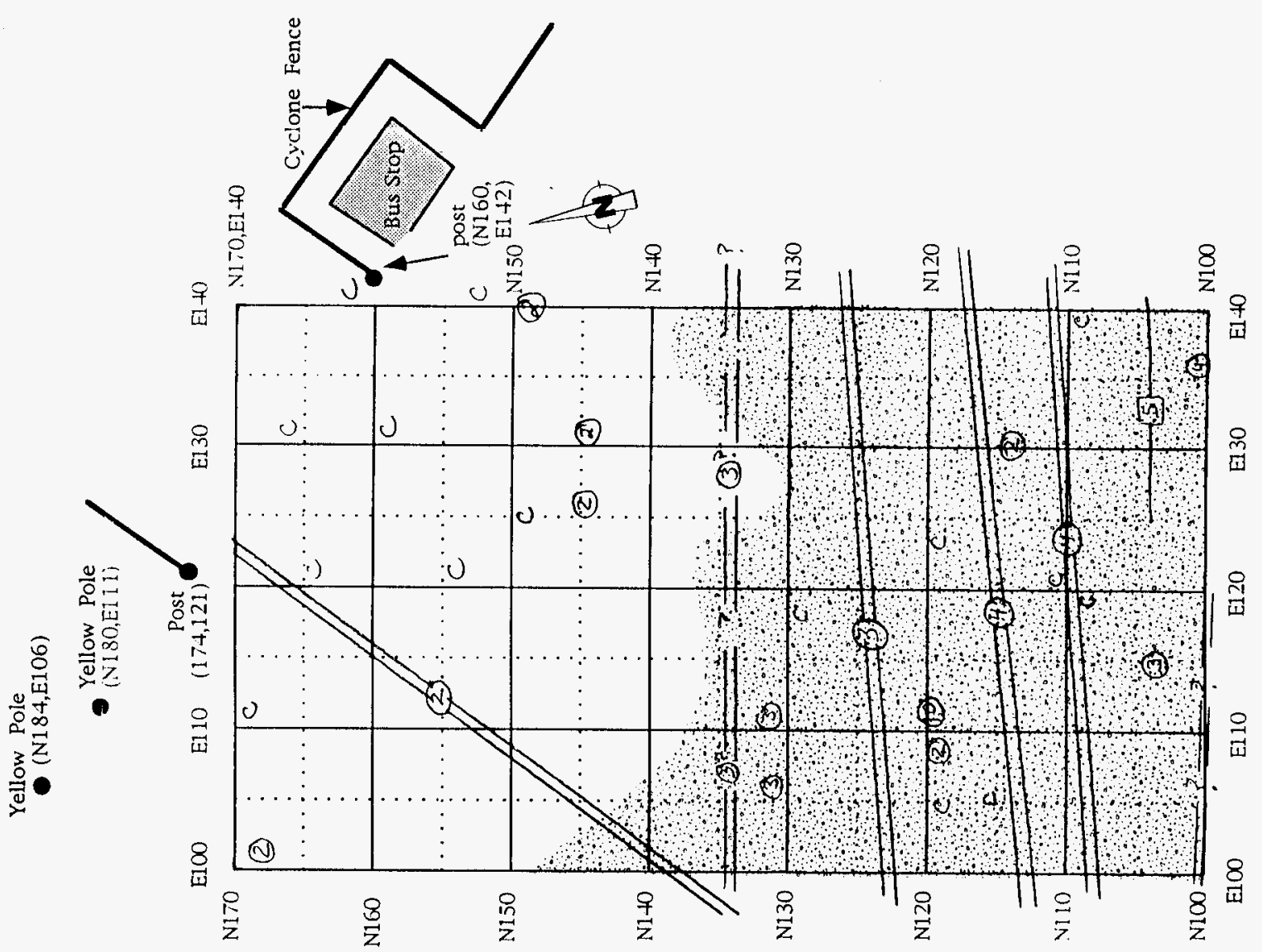




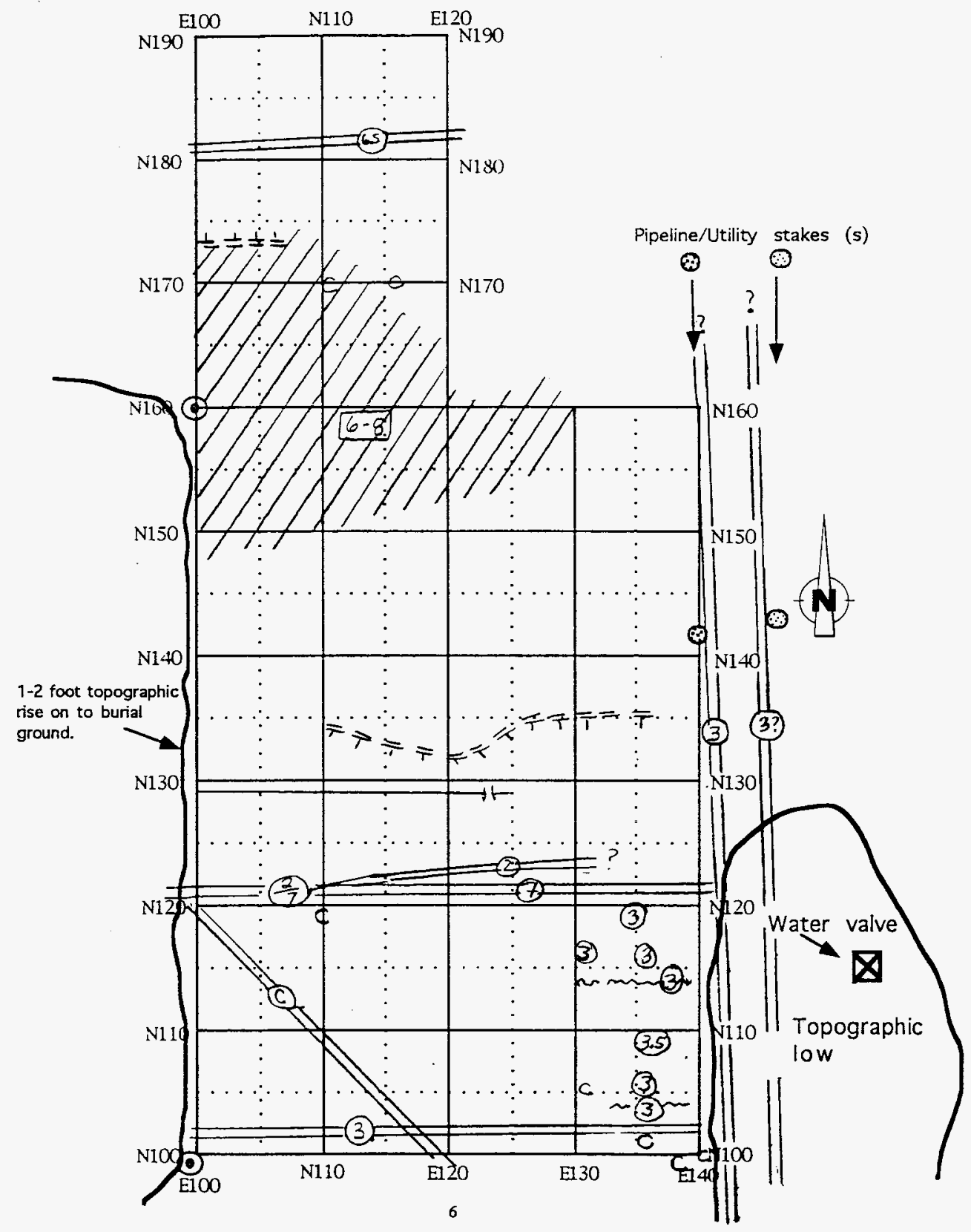

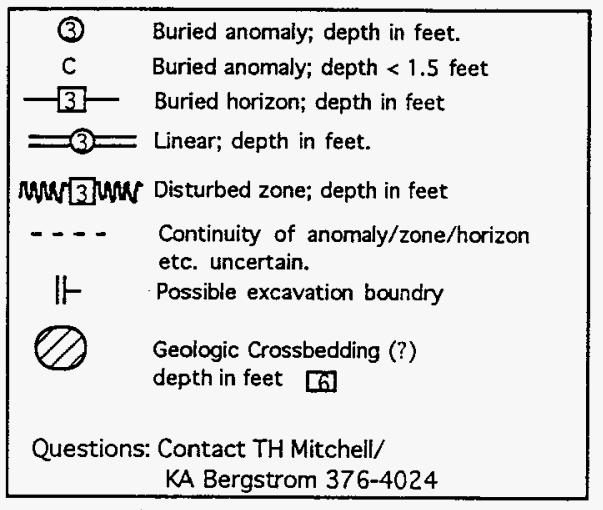

Figure 2. Interpretation map of geophysical survey over the $216-\mathrm{U}-1 / 2$ pipeline, site \#1 (west). 


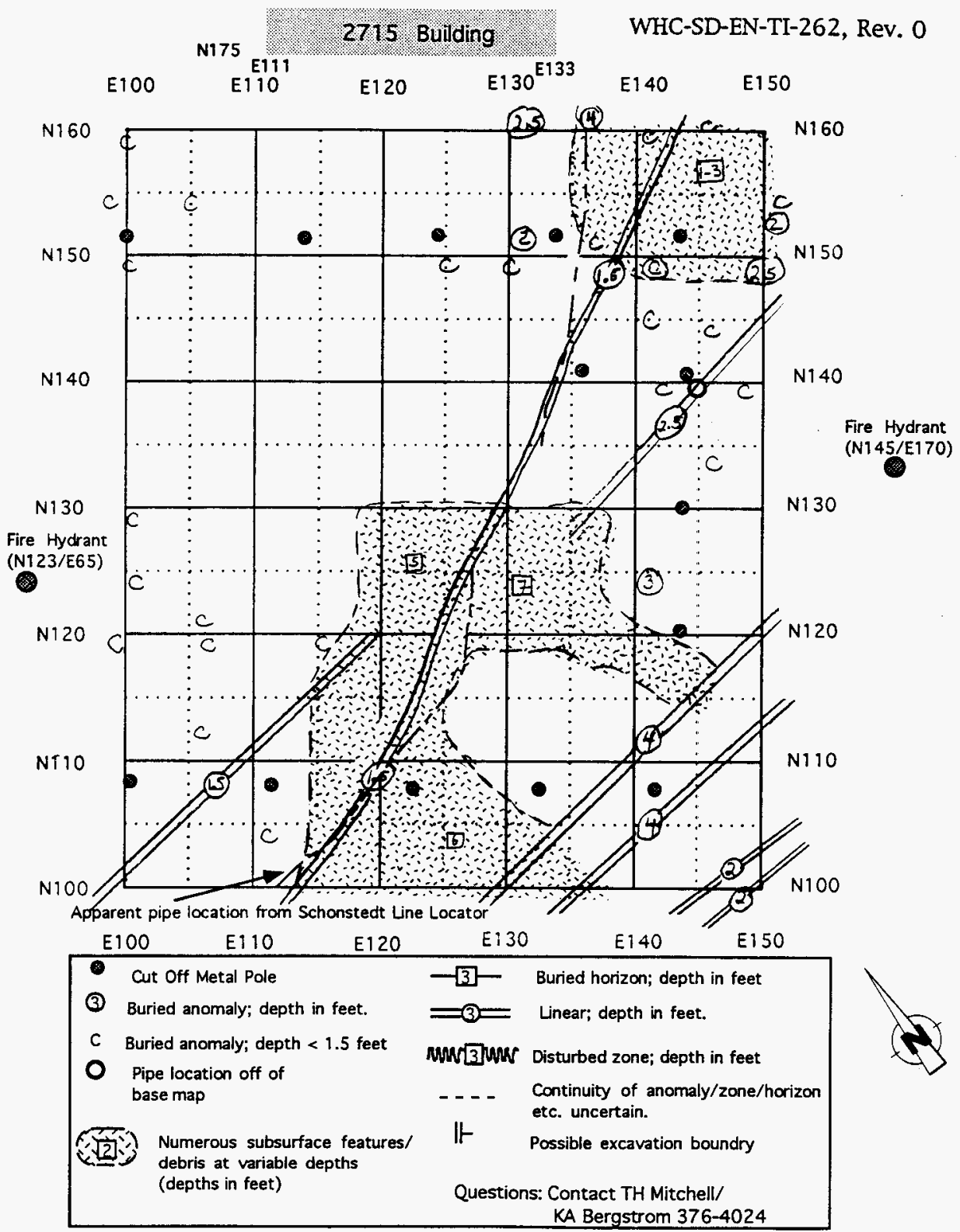

Figure 4. Interpretation map of geophysical survey over the $216-\mathrm{U}-1 / 2$ pipeline, site \#3 (east). 
WHC-SD-EN-T1-262, Rev. 0

\section{GROUND-PENETRATING RADAR (GPR) SURVEY}

Team Geophysics, Westinghouse Hanford Operations

\begin{tabular}{|l|l|}
\hline TITLE: $216-U-1 / 2$ pipeline, Site \#1 (west) & DATE: $\quad 4 / 21 / 94$ \\
\hline
\end{tabular}

LOCATION:

South of $216-\mathrm{U}-1$ \& 2 cribs. On south side of road and steam line, 200 West.

\begin{tabular}{|l|l|}
\hline CLIENT: Craig Rowley & $\begin{array}{l}\text { DATA COLIECTED BY } \\
\text { K.A. Bergstrom \& G.J. Szwartz }\end{array}$ \\
\hline EQUIPMENT USED: & ANTENNA(S) USED: \\
$\begin{array}{l}\text { GSSI System 8, model 4800 } \\
\text { Calibrator Model P731 }\end{array}$ & $100 \quad 300$ XX 100 BISTATIC \\
\cline { 2 - 2 } $\begin{array}{l}\text { Digital Tape Recoder DT6000A } \\
\text { LOG BOOK: EFL1122 }\end{array}$ \\
\cline { 2 - 2 } & TIME WINDOW (NS): 100 \\
\hline
\end{tabular}

PROCEDURES FOLLOWED: WHC-CM-7-7 EII 11.2, REV. 3

GRID : $90 \times 40^{\prime}$ NO. OF PROFILES: $\_34$ TOTAL FOOTAGE COLLECTED: 1600

PARAMETERS: Two sets of perpendicular profiles; five feet between north-south profiles and five feet between east-west profiles.

DATA TAPE NO.: 94-17 RECORDS LOCATION: Geophysical field files

TAPE ADDRESS $: \underline{30227-45589}$ CALIRRATION ADDRESS: $45589-45746$

INTERPRETED BY : K.A. Bergstrom REVIEWED BY : G.J. SzwartZ

INTERPRETATION DELIVERED TO Craig Rowley DATE :

OBJECTTVE(S):

To locate 216-U-1/2 Pipeline in two different places. Pipe is thought to be stainless steel.

NOTES:

Antenna pulled by hand at 1-2 mph. 30-meter cable.

Figure 5. GPR Parameters for 216-U-1/2 Pipeline, Site \#1 (west). 
WHC-SD-EN-TI-262, Rev. 0

\section{GROUND PENETRATING RADAR (GPR) SURVEY}

Team Geophysics, Westinghouse Hanford Operations

\begin{tabular}{|l|l|} 
TITLE: Borehole $216-U-1 / 2$ pipeline, Site \#2 (central) & DATE: $4 / 25 / 94$ \\
\hline
\end{tabular}

LOCATION:

East of $216-U-1$ \& 2 cribs, 200 West. Southwest side of the $224 U$ southwest perimeter fence gate.

\begin{tabular}{|l|l|}
\hline CLIENT: Craig Rowley & $\begin{array}{l}\text { DATA COLLECTED BY } \\
\text { K.A. Bergstrom \& T.H. Mitchell }\end{array}$ \\
\hline $\begin{array}{l}\text { EQUIPMENT USED: } \\
\text { GSSI System 8, model 4800 }\end{array}$ & $\begin{array}{l}\text { ANTENNA(S) USED: } \\
100 \_300 \_X X \\
\end{array}$
\end{tabular}

Calibrator Model P731

Digital Tape Recoder DT6000A

LOG BOOK: EFL 1122

TMME WINDOW (NS): 100

PROCEDURES FOLLOWED: WHC-CM-7-7 EII 11.2, REV. 3

GRID : $70 \times 40^{\prime}$ NO. OF PROFILES: 24 TOTAL FOOTAGE COLLECTED: 1300

PARAMETERS: Two sets of perpendicular profiles; five feet between north-south profiles and five feet between east-west profiles.

DATA TAPE NO.: 94-18 RECORDS LOCATION: Geophysical field files

TAPE ADDRESS :-0-11179 CALIRRATION ADDRESS: 11179-11303

INTERPRETED BY : _ G.J.SZWartz _ REVIEWED BY : K.A. Bergstrom

INTERPRETATION DELIVERED TO Craig ROWley DATE :

OBJECTTVE(S):

To locate 216-U-1/2 Pipeline in two different places. Pipe is thought to be stainless steel.

NOTES:

Antenna pulled by hand at $1-2 \mathrm{mph}$. 30 -meter cable.

Figure 6. GPR Parameters for 216-U-1/2 Pipeline, Site \#2 (central). 
WHC-SD-EN-TI-262, Rev. 0

\section{GROUND PENETRATING RADAR (GPR) SURVEY}

Team Geophysics, Westinghouse Hanford Operations

TITLE: $\quad 216-U-1 / 2$ pipeline, Site \#3 (east)

DATE: $\quad 5 / 17 / 94$

LOCATION:

Southeast of the 224-U building, between the building and the perimeter fence.

\begin{tabular}{|l|l|}
\hline CIIENT: Craig Rowley & $\begin{array}{l}\text { DATA COLIECTED BY } \\
\text { T.H. Mitchell \& K.A. Bergstrom }\end{array}$ \\
\hline $\begin{array}{l}\text { EQUIPMENT USED: } \\
\text { GSSI System 8, model 4800 }\end{array}$ & ANTENNA(S) USED: \\
$\begin{array}{l}\text { Calibrator Model P731 } \\
\text { Digital Tape Recoder DT6000A }\end{array}$ & $100 \quad 300$ XX 100 BISTATIC \\
\cline { 2 - 2 } & LOG BOOK: EFL 1122 \\
\cline { 2 - 3 } & TIME WINDOW (NS): 100 \\
\hline
\end{tabular}

PROCEDURES FOLLOWED: WHC-CM-7-7 EII 11.2, REV. 3

GRID : $50^{\prime} \times 60^{\prime}$ NO. OF PROFILES: 24 TOTAL FOOTAGE COLIECTED: _ 1310

PARAMETERS: Two sets of perpendicular profiles; five feet between north-south profiles and five feet between east-west profiles.

DATA TAPE NO.: 94-20 RECORDS LOCATION: Geophysical field files

TAPE ADDRESS : 38180-57802 CALIBRATION ADDRESS: 30706-30850

INTERPRETED BY : I.H. Mitchell__ REVIEWED BY : K.A. Bergstrom

INTERPRETATION DELIVERED TO Craig Rowley DATE :

OBJECTIVE(S):

To locate 216-U-1/2 Pipeline in two different places. Pipe is thought to be stainless steel.

NOTES:

Antenna pulled by hand at $1-2 \mathrm{mph} .30$-meter cable.

Figure 7. GPR Parameters for 216-U-1/2 Pipeline, Site \#3 (east). 


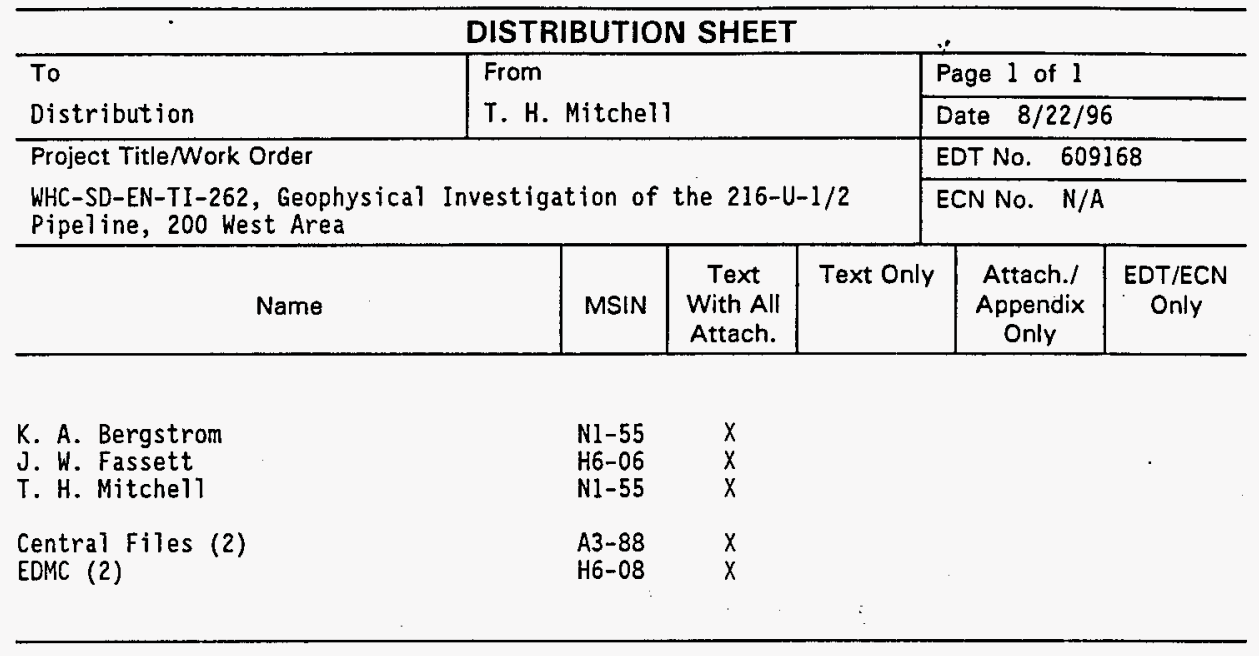

